\title{
The impact of a peer coaching programme on the academic performance of undergraduate students: a mixed methods study
}

\author{
Jill Andreanoff \\ University of Essex, UK
}

\section{Abstract}

Peer support interventions have been widely used within the higher education sector as a means to enhance student success and retention. However, much of the evidence to measure the impact of mentoring and coaching has relied on anecdotal, self-reported evidence from the participants. In addition, there is much confusion in the terms to describe peer support interventions, making it difficult to compare and contrast the different programmes. The need for evidence of a more robust, quantitative nature has long been called for by a number of authors such as Jacobi (1991), Capstick et al. (2004) and Medd (2012). This mixed methods case study of an extant peer coaching programme in higher education in the UK makes explicit the process of the coaching intervention, measuring the impact on academic attainment in the form of module grade data. In addition, the use of a control group enables a comparison to be made of the academic attainment of non-coached students with those who received peer coaching. Academic behaviour confidence of those who were coached was also measured pre- and postcoaching using the Sander and Sanders (2009) ABC questionnaire. There was found to be a significant impact in the attainment of students who received coaching when compared to those students in the control group who did not. The peer coaching had a beneficial impact in particular for those in their first year of study and those who were performing less well at the outset, as well as students within the Business School. A significant increase in the academic behaviour confidence was found in those who received coaching as well as a reduced attrition rate when compared to those in the control group.

Keywords: peer coaching; academic attainment; higher education students; mentoring. 


\section{Background}

Peer support interventions for students have been implemented for several years by many Higher Education Institutions (HEIs). Authors such as Tinto (1993), Astin (1984), Goodlad (1998) and Kuh et al. (2003) advocate student involvement with their institution as a means to reduce attrition rates and as a predictor of student success. Ward et al. (2010) found that goals were more likely to be obtained by those being mentored and Griffin (1995), Hill and Reddy (2007), and Andrews and Clark (2011) all reported benefits such as improved student engagement and satisfaction.

However, there is a growing body of literature available that highlights the confusion between the terms used to describe peer support and the precise nature of the interventions. This confusion was emphasised by Gibson (2005) and Chao (1998) who reproach others for not clarifying their definition of the terms in their studies. Jacobi (1991) and D'Abate et al. (2003) report that the lack of clarity in the terms makes it difficult to compare and contrast the different interventions. Jacobi (1991) first reported this difficulty and D'Abate et al. (2003) in her review of mentoring and coaching mirrored these same concerns. Parsloe and Wray (2000) also recognised the confusion between the terms coaching and mentoring. Donegan et al. (2000) describe the process as an expert teacher giving support, feedback and making suggestions to untrained or less skilled peers, indicating a more directive approach. Stober and Grant (2006) and Ives (2008) discuss the different approaches and contexts in which coaching is used. Whilst advice giving is discouraged in some definitions, in others 'guidance' is stated as part of the process. Coaching is often described as 'goal focused' and a shorter term activity concerned with maximising performance (Whitmore, 2002). Mentoring is often thought to be more of a transfer of knowledge as described by Parsloe and Wray (2000).

Despite this confusion, the presented evidence seems to suggest that peer support interventions are useful in attaining many objectives. The methodology more commonly adopted to study the impact of these interventions relies heavily on anecdotal evidence. Many studies refer to increased student success, although success is often defined by social integration or increased student involvement with the $\mathrm{HEI}$ rather than academic attainment. 
Some studies have used quantitative evidence to determine the impact of peer support initiatives but have been quite specialised, limiting the transferability of the findings, or have adopted inadequate methodology. For example, Fox and Stevenson (2005) conducted a quantitative study of accounting and finance students who were mentored compared to a control group of students who were not. Whilst the findings did report higher attainment in those being mentored, the intervention was described as pre-determined group sessions, which some would argue is not 'mentoring'. Sanchez et al. (2006) carried out a longitudinal study that reported improved satisfaction and commitment of students to complete their studies compared to a non-mentored group. However, the sample size was significantly reduced by the end of the study, resulting in missing data compromising the validity of the findings. This intervention too was described as having a team leader working with small groups of students. The study by Short and Baker (2010) determined the impact of peer coaching, this time a one-to-one intervention but the small sample size of eight participants reduced the reliability of the quantitative evidence.

This mixed method study focuses specifically on the academic attainment of higher education students using quantitative data collected from a sample size of 150 coached students and a control group of 93 non-coached students selected from eight different academic schools. It aimed to determine how academic attainment is impacted through a robust peer coaching programme. The coaching was offered over a 10-12 week period and promoted specifically to students as a means to improve grades. It comprised of oneto-one meetings with a coachee led agenda rather than predetermined group sessions, with a suggested guideline of one hour, weekly meetings. With such a result-orientated objective, coaching can be considered an appropriate label to adopt. Peer coaches are trained to refrain from 'advice giving' not only to avert the possibility of the coaches giving incorrect advice but to create a less directive relationship that is better aligned to lead to self-efficacy in the coachee.

The research takes a case study approach conducted within one UK based HEI selected due to the well-established peer support programmes delivered there. This includes mentoring which is offered for a year's duration, has the aim of improving social integration, and is targeted at those from lower socio economic groups, whilst the peer coaching is offered to all students. A dedicated team of eight staff are in place to deliver the programmes and over 300 students are recruited and trained each year to take part. Once trained, the peer coaches and mentors support over 1,000 students. This study 
focuses on the undergraduate peer coaching programme that uses older and more experienced students to support younger less experienced ones.

The programmes at the case study institution all adhere to good practice as defined by Husband and Jacobs (2009), Andrews and Clark (2011) and Thomas (2012). These authors identified the need for a well-structured programme to be in place in order to meet objectives. Coaches and mentors are selected, following interview, having provided a full application form. For the peer coaching, a good academic attainment record is essential in addition to personal attributes such as well-developed communication skills. Once accepted, the student coaches undergo a mandatory two day training programme that culminates in an assessment to test their knowledge and understanding of the coaching role. The training actively encourages the students to refrain from 'advice giving' and instead teaches effective questioning techniques to help facilitate self-efficacy in the coachees through goal and target setting. Coaches are also reminded about the risks of collusion and plagiarism.

Coachees apply for a peer coach through an application process and are involved in the matching process following a mandatory induction to define their role in the relationship. The coaches are offered fortnightly support workshops throughout the process to further develop their coaching skills and assist with any issues arising from the developing relationships.

\section{Methodology}

The purpose of the study was to explore whether peer coaching improved academic performance and provide a greater understanding of the impact on coachee attainment. Qualitative data illuminated the quantitative findings and made a mixed methods approach a logical methodology to adopt. Johnson and Onwuegbuzie (2004, p.16) state that 'research approaches should be mixed in ways that offer the best opportunity for answering important research questions'. Creswell and Plano Clark (2011) describe a convergent parallel type of design as one where concurrent timing is implemented to the quantitative and qualitative strands during the same phase of the research process. The design prioritises the methods equally but keeps the two strands independent during analysis mixing the results during the overall interpretation. They suggest that the 
convergent design is best when there is a need to corroborate quantitative data using pragmatism as an umbrella philosophy. In this study, module grade data was compared with the student perception data collected, exploring any commonalities or incongruities. The overall design comprised of QUAN + QUAL and the quantitative data was stored and manipulated using SPSS.

The research comprised of 150 undergraduate participants who elected to be peer coached. Data was accessed on their academic performance both prior to being coached and post-coaching. In addition to this, qualitative data was collected via semi-structured interviews and six focus groups. 21 students who were coached took part in ether a oneto-one interview or one of four focus groups and fourteen coaches took part in a further two focus groups. Participants were asked about their perceptions of the coaching process and perceived impact on academic performance. Interviews and focus groups were conducted by three researchers who had no involvement with the delivery of the peer coaching programme for avoidance of possible respondent bias. Themes were drawn independently from the data and compared as a means of investigator triangulation. Tables 1.1 and 1.2 show information on the students who received coaching.

Table 1.1. Breakdown of student participants who took part in the peer coaching.

\begin{tabular}{|c|c|c|}
\hline $\begin{array}{c}\text { Academic School } \\
\text { Life \& Medical Sciences }\end{array}$ & $\begin{array}{c}\text { Number of peer } \\
\text { coachees }\end{array}$ \\
\hline Law School & 20 & 30 \\
\hline Business School & 17 & 23 \\
\hline Engineering & 21 & 40 \\
\hline Physics, Astronomy \& Maths & 7 & 13 \\
\hline Humanities & 8 & 13 \\
\hline Education & 9 & 16 \\
\hline Nursing & 8 & 14 \\
\hline Total Number & 1 & 150 \\
\hline
\end{tabular}


Table 1.2. Breakdown of students into separate year groups.

\begin{tabular}{|l|l|l|l|l|}
\hline Year & $\mathbf{1}^{\text {st }}($ level 4) & $\mathbf{2}^{\text {nd }}($ level 5) & $\mathbf{3}^{\text {rd }}($ level 6) & $\mathbf{4}^{\text {th }}$ year \\
\hline $\begin{array}{l}\text { Number of } \\
\text { students }\end{array}$ & 82 & 52 & 14 & 2 \\
\hline
\end{tabular}

As well as being asked about their perceptions of the coaching, coachees were also asked pre- and post-coaching to comment upon their level of confidence and satisfaction in the following areas using a 7 point Likert scale:

- How satisfied they were with their academic progress so far.

- How they felt they were managing the requirements of their course.

- How satisfied overall they were with student life.

Whilst the peer coaching was not designed to enhance student satisfaction, there would likely be a link with this and academic performance, as has been explored by McKenzie and Schweitzer (2001) and Martirosyan et al. (2014).

A control group of 93 participants were also selected comprising of students who were offered peer coaching but declined through choice, as can be seen in Tables 1.3 and 1.4. Similar data on academic achievement was collected for the control group students for comparison. Care was taken when inviting the control group to avoid bias, contamination and pre-existing attributes, as described by Mosley (1997). 
Table 1.3. Breakdown of student participants in the control group.

\begin{tabular}{|c|c|}
\hline Academic School & Number of students \\
\hline Life \& Medical Sciences & 20 \\
\hline Law School & 18 \\
\hline Business School & 35 \\
\hline Engineering & 9 \\
\hline Physics, Astronomy \& Maths & 1 \\
\hline Humanities & 7 \\
\hline Education & 3 \\
\hline Nursing & 0 \\
\hline Total Number & $\mathbf{9 3}$ \\
\hline
\end{tabular}

Table 1.4. Breakdown of control group students into separate year groups.

\begin{tabular}{|l|c|c|c|c|}
\hline Year & $\mathbf{1}^{\text {st }}($ level 4) & $\mathbf{2}^{\text {nd }}($ level 5) & $3^{\text {rd }}($ level 6) & $\mathbf{4}^{\text {th }}$ year \\
\hline $\begin{array}{l}\text { Number of } \\
\text { students }\end{array}$ & 48 & 39 & 6 & 0
\end{tabular}

Academic progress of both the control group and the peer coached group was explored and compared using independent $t$ tests. In addition to this, the Sander and Sanders (2009) academic behaviour confidence (ABC) questionnaire was administered to the coached group, both pre- and post-coaching. This questionnaire is designed to measure confidence levels in relation to academic behaviours which are recognised as being required for success in higher education. Data from the Likert scales was quantitized, enabling further statistical analysis. Table 1.5 shows the types and numbers of data collected. 
Table 1.5. Types and numbers of data samples collected.

\begin{tabular}{|l|c|c|c|c|}
\hline & \multicolumn{2}{|c|}{ PERCEPTION DATA } & \multicolumn{2}{c|}{ PERFORMANCE DATA } \\
\hline & $\begin{array}{c}\text { Post-coaching } \\
\text { perceptions of } \\
\text { student } \\
\text { satisfaction } \\
\text { and academic } \\
\text { performance }\end{array}$ & $\begin{array}{c}\text { Post-coaching } \\
\text { Sander and } \\
\text { Saunders - } \\
\text { ABC } \\
\text { questionnaire }\end{array}$ & $\begin{array}{c}\text { Module Grade } \\
\text { Data- } \\
\text { Semester A }\end{array}$ & $\begin{array}{c}\text { Module Grade } \\
\text { Data- } \\
\text { Semester B }\end{array}$ \\
\hline $\begin{array}{l}\text { Coached } \\
\text { Group }\end{array}$ & $\begin{array}{c}65 \\
(150 \text { collected } \\
\text { pre-coaching })\end{array}$ & $\begin{array}{c}63 \\
(150 \text { collected } \\
\text { pre-coaching })\end{array}$ & 146 & 127 \\
\hline Control Group & Not collected & Not Collected & 92 & 72 \\
\hline
\end{tabular}

\section{The qualitative findings}

\section{Student perception data}

The semi-structured interviews used as part of the focus groups enriched and helped elucidate the quantitative data collected, putting the peer coaching process into context. Four themes emerged from the transcripts.

\section{Theme 1 - Academic improvement}

There were a number of students who directly attributed the coaching intervention to their improved academic grades:

Towards the end I could see it clearly that my grades, which at the start were at 2:1, went straight to a $1^{\text {st }}$ which is what we aimed at achieving. So overall I would say that because of her support I am more confident in my academic work. (Law student)

Other students similarly remarked on their improvement: 


\section{Figure 1. Academic improvement.}

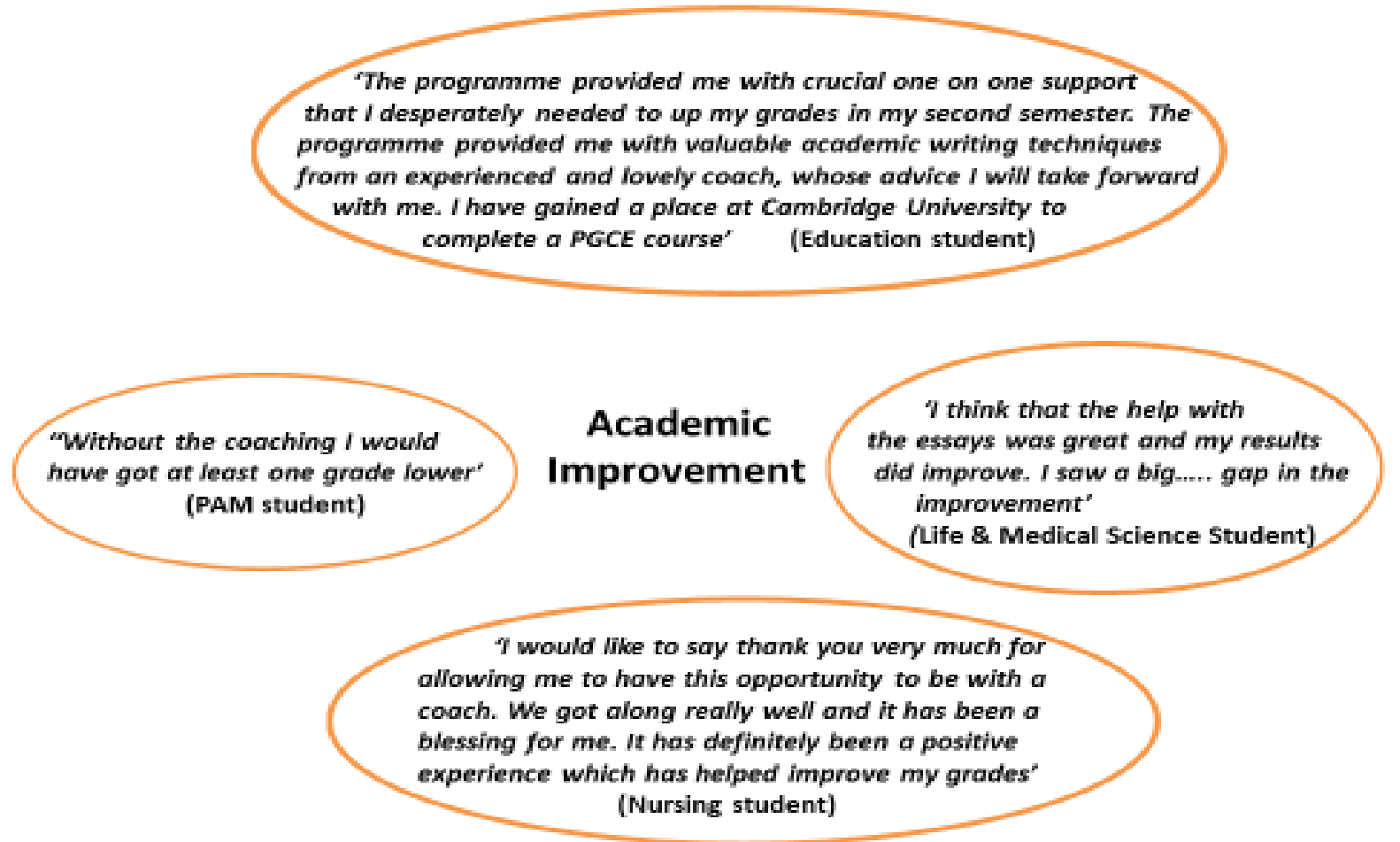

Many of the students made a connection between improved grades and greater academic confidence. Rather than refer to a vague notion of performing better they were able to specifically identify the particular area where they had noticed an improvement:

\section{Figure 2. Academic confidence.}

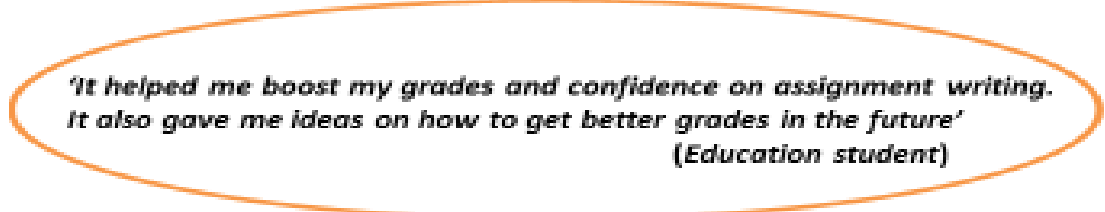

$T$ was getting a first and $a$ high 2:1 and now I'm getting $a$ high first'

(Law student)
'As a result I got a first in my Management for Business essay.

(Business School student)

7 have managed to get higher grades and I am more confident now'

(Humanities student) 
The quotes above illustrate the perceived impact on academic performance as seen by the coachees. It is clear from these findings that the students perceived themselves to be performing better academically.

\section{Theme $\mathbf{2}$ - Increased confidence and motivation}

Many students reported improved confidence and motivation as a result of the coaching which was also apparent from the survey questionnaire data. Figure 3 provides evidence illustrating increased confidence attributed to the support provided by the peer coaching:

Figure 3. Examples of how coaching increased confidence and motivation.

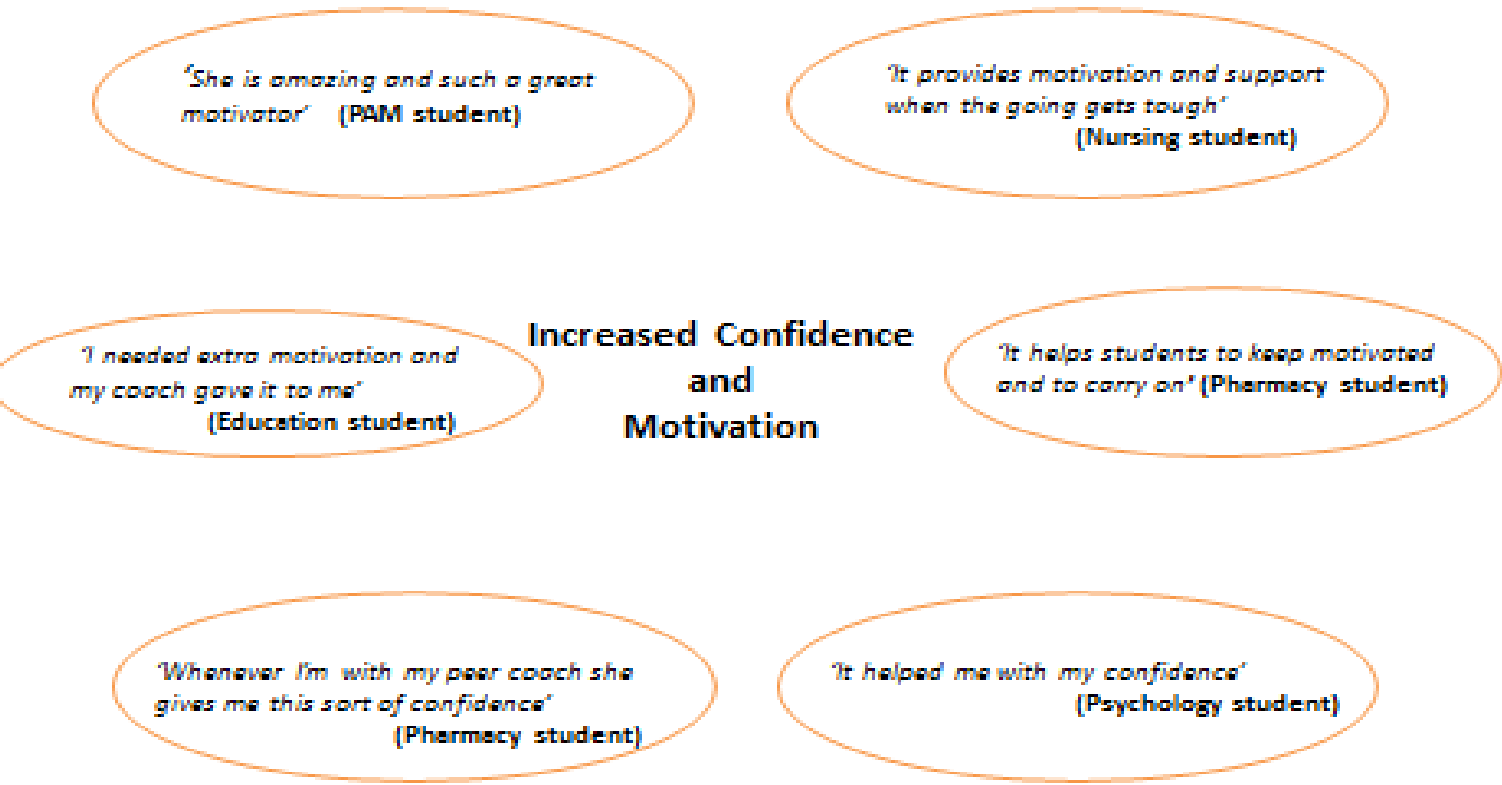

This perceived increase in motivation could have a beneficial impact on higher education students. It has been found in previous studies that where students display low academic self-efficacy they are more likely to lose motivation. Bandura (1993), for example, reported that students may give up persisting with academic tasks. Torres and Solberg (2001) and Zajacova et al. (2005) state that students might also lose motivation and spend less time studying and preparing for tutorials. This evidence to suggest increased levels of motivation is therefore likely to impact positively on academic attainment and persistence. 


\section{Theme 3 - Examples of the value of one-to-one support}

Nineteen students commented on the beneficial nature of the one-to-one aspect of the programme in their post-coaching questionnaires and the preference for speaking to a peer rather than seeking help from their tutor, which can be seen in Figure 4.

\section{Figure 4. Supporting the theme 'One-to-one support'.}
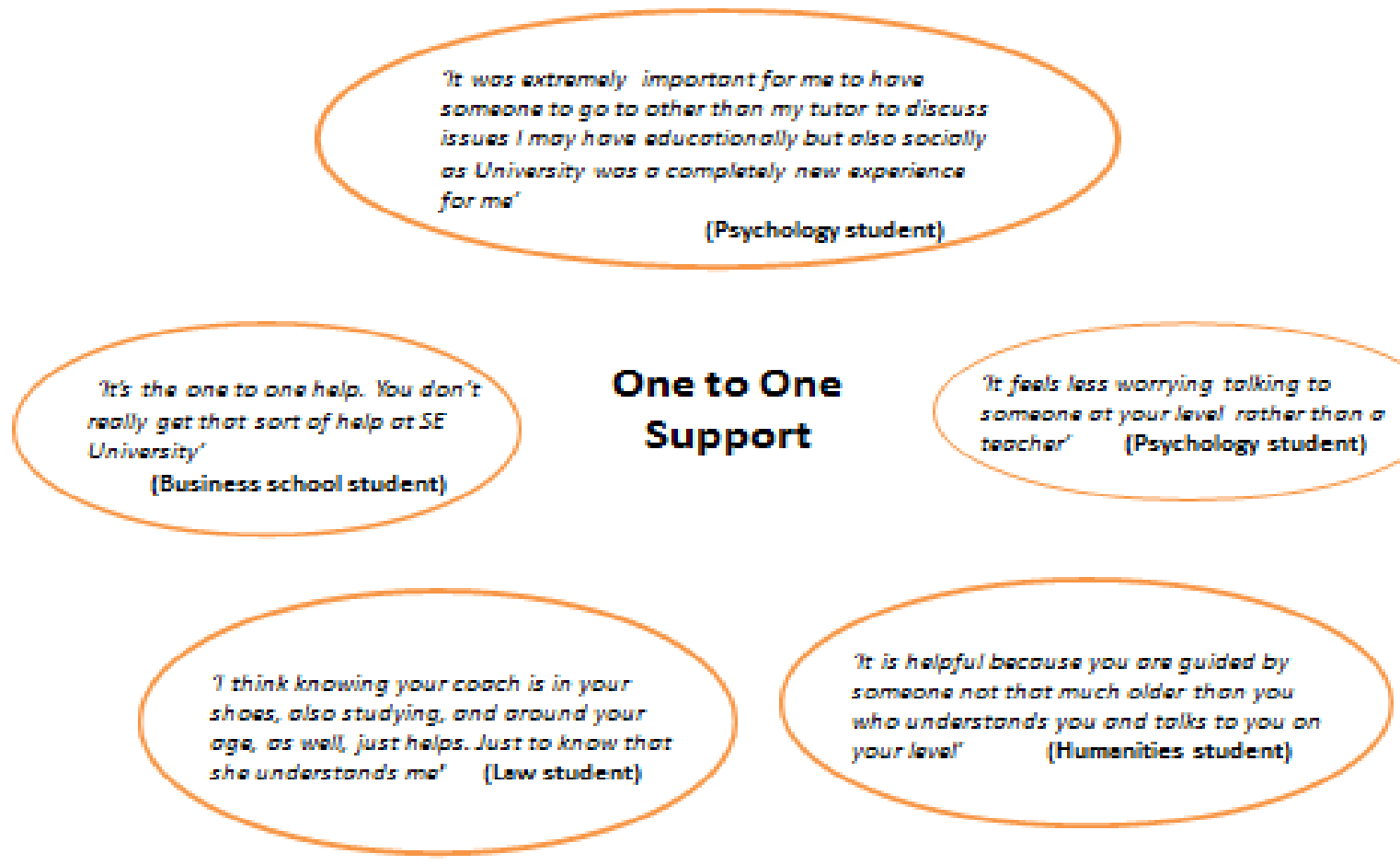

Whilst other interventions such as student support sessions, delivered by staff, are available at the case study university, it can be seen from the extracts that it is particularly valued when the support is offered by a peer. Similar findings have been reported for peer assisted learning (PAL) by Capstick et al. (2004) who found that students taking part in PAL enjoyed being able to discuss academic concerns away from teaching staff. In this study the participants also noted the benefits of one-to-one peer support.

\section{Theme 4 - Practical and emotional support}

Many of the coachees cited the practical help that they were given as being valuable. This concurs with the findings from the Sander and Sanders (2009) ABC scale data that is explored later, suggesting that academic behaviour confidence had improved from pre- to 
post-coaching. Coachees were able to identify in what way the peer coaching had assisted them from simply organising their time more efficiently to setting actions, as the following extracts suggest.

Figure 5. Practical and emotional support.

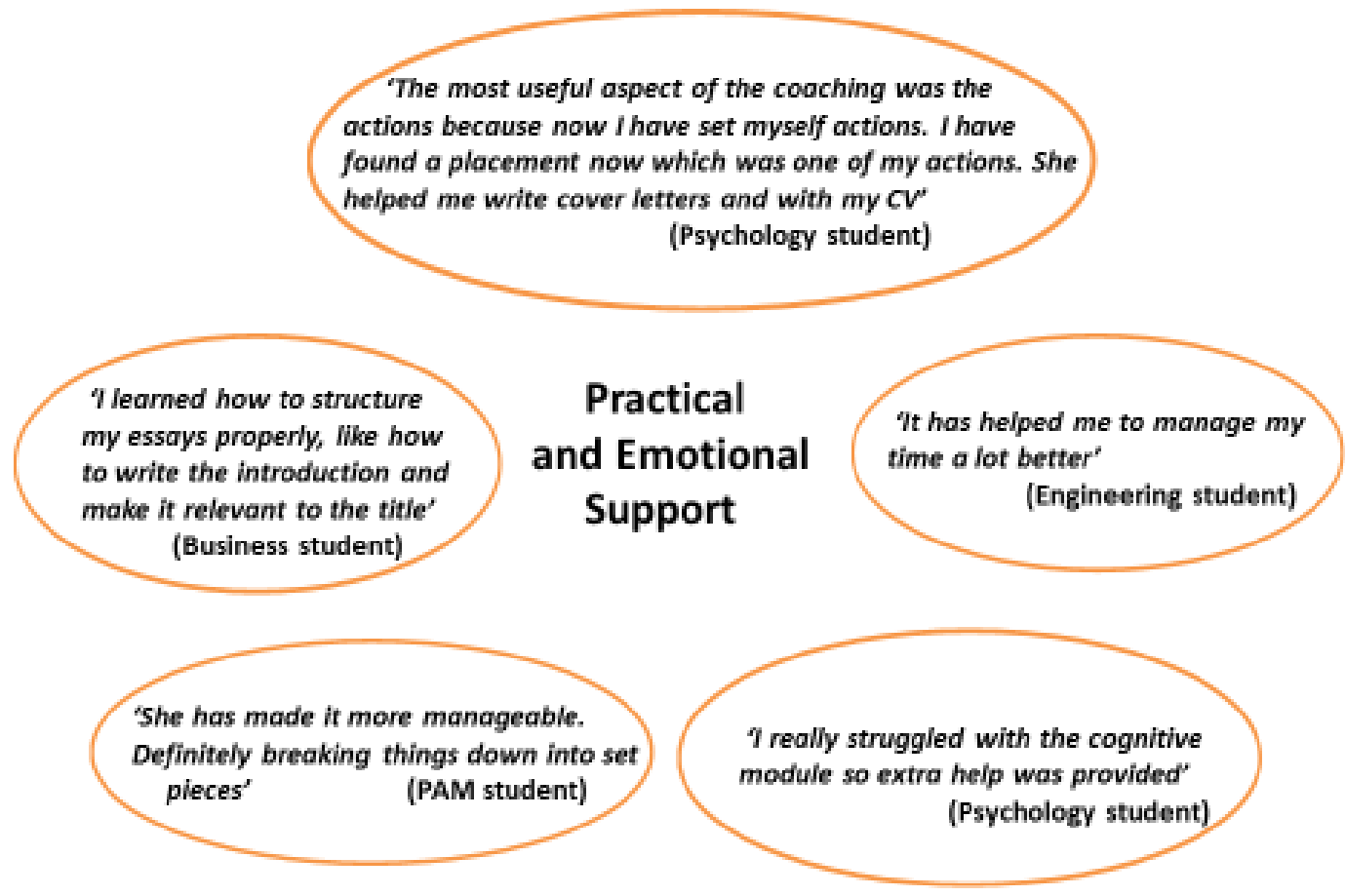

These quotes and extracts demonstrate the practical support that was offered by the coaches to the coachees. It also demonstrates that the 'coaching practice' is in line with the training given, with the coaches identifying goals, breaking down tasks into more manageable ones, and agreeing actions for the coachee to follow. This approach is also likely to lead to improved self-efficacy in the coachees through the achievement of small goals (Ives and Cox, 2012).

It can be seen from the evidence that the peer coaching has been instrumental in bringing an increased understanding of the requirements for success in higher education study. Having the opportunity to share experiences with a more experienced student has led to the enlightenment of the less experienced students as to academic expectations. As students were matched with those studying the same or a similar course, this sharing of experiences was seen to be particularly beneficial by the coachees: 
My peer coach helped me to understand what was required from me for my course.

(Biomedical Science Student)

This aspect of peer coaching may be particularly beneficial for those students who are from widening participation backgrounds who have not had the advantage of parental involvement in higher education:

It was extremely important for me to have someone to go to other than my tutor to discuss issues I may have... as university was a completely new experience for me.

(Law Student)

This enlightenment and improved understanding of the requirements of their course and for success could be a key factor in the impact of the peer coaching. A link has been found to suggest that students with unrealistic expectations about the nature of teaching and learning in higher education are more likely to withdraw from their studies (Charlton et al., 2006; Lowe and Cook, 2003; Yorke, 2002). Nicholson et al. (2013) suggest that students will perform better if they have realistic expectations of personal responsibility for independent study in higher education. The peer coaching has demonstrated to facilitate this type of knowledge acquisition.

\section{The quantitative findings}

\section{Student satisfaction}

Paired sample t-tests were calculated to determine whether there was a statistical increase in perceived student satisfaction and confidence levels from pre- to postcoaching. There was found to be a statistically significant increase in student satisfaction with their academic progress from pre-coaching $(M=3.56, S D=1.45)$ to post-coaching ( $M$ $=4.30, \mathrm{SD}=1.43), \mathrm{t}(60)=3.65, \mathrm{p}<.0005$ (two-tailed). The mean increase in satisfaction with academic progress was 0.74 with a $95 \%$ confidence interval ranging from 1.14 to 0.33. The eta squared statistic (.18) indicated a LARGE effect size.

There was also a statistically significant increase in the students' perception of how they were managing their course requirements from pre-coaching $(M=3.98, S D=1.41)$ to post-coaching $(M=4.72, S D=1.37)$, $t(59)=4.24, p<.0005$ (two tailed). The mean increase in perception of being able to manage their course requirements was 0.74 with a 
$95 \%$ confidence interval ranging from 1.08 to 0.39 . The eta squared statistic (.24) also indicated a LARGE effect size.

There was also a statistically significant increase in the students' satisfaction with student life from pre coaching $(M=4.24, S D=1.48)$ to post-coaching $(M=4.77, S D=1.30)$, $t(61)$ $=3.07, p<.0005$ (two-tailed). The mean increase in satisfaction with student life was .53 with a $95 \%$ confidence interval ranging from 0.88 to 0.19 . The eta squared statistic (.13) indicated a MODERATE effect size.

These results would indicate that the students perceived themselves to be performing better academically, were more satisfied with their academic progress, and with general student satisfaction from pre- to post-coaching.

\section{Academic confidence}

The Sander and Sanders (2009) Academic Behaviour Confidence (ABC) scale was also administered both pre- and post-coaching. This enables self-efficacy and self-concept to be measured on academic confidence only. Self-efficacy has been demonstrated to be instrumental in academic success as has been reported by Pajares and Schunk (2006), Crozier (1997), and Sander and Sanders (2009). In particular within a higher education context where autonomy and independence of students are essential to success, it is said to affect academic performance. The full table of pre and post results can be found in Appendix 1.

From these calculations it was seen that there was an increase in the mean scores of all 24 aspects of self-efficacy from pre- to post-coaching. The Eta squared statistic was calculated to determine the effect size of each item using Cohen's d (1998) guideline, where .01 is a small effect, .06 is a moderate effect, and .14 is a large effect. The least impact or movement was seen with 'attending tutorials', although the initial pre-coaching mean score for this question was relatively high at 4.2. As the aim of the coaching was academically focused, it is not surprising that 'Making the most of the opportunity of studying for a degree at university' showed little change from pre- to post-coaching. The more social aspects of attending university were not stated to be a particular focus for the peer coaching intervention. There was, however, a LARGE statistically significant increase from pre- to post-coaching items as shown in Table 1.6 using Cohen's (1998) calculation. 
Table 1.6. showing items where a large significant increase from pre- to postcoaching was identified.

\begin{tabular}{|l|c|c|c|}
\hline \multicolumn{1}{|c|}{ QUESTION } & $\begin{array}{c}\text { Pre- } \\
\text { coaching } \\
\text { mean }\end{array}$ & $\begin{array}{c}\text { Post- } \\
\text { coaching } \\
\text { mean }\end{array}$ & $\begin{array}{l}\text { Increase/ } \\
\text { decrease }\end{array}$ \\
\hline $\begin{array}{l}\text { Study effectively on your own in independent/private } \\
\text { study }\end{array}$ & 3.35 & 3.92 & +0.57 \\
\hline $\begin{array}{l}\text { Produce your best work under examination } \\
\text { conditions }\end{array}$ & 2.59 & 3.33 & +0.74 \\
\hline $\begin{array}{l}\text { Respond to questions asked by lecturer in front of a } \\
\text { full lecture theatre }\end{array}$ & 2.57 & 3.12 & +0.55 \\
\hline $\begin{array}{l}\text { Manage your workload to meet coursework } \\
\text { deadlines }\end{array}$ & 3.27 & 3.98 & +0.71 \\
\hline $\begin{array}{l}\text { Give a presentation to a small group of fellow } \\
\text { students }\end{array}$ & 3.43 & 3.88 & +0.45 \\
\hline Attain good grades in your work & 3.08 & 3.70 & +0.62 \\
\hline $\begin{array}{l}\text { Ask lecturers questions about the material they are } \\
\text { teaching, during a lecture }\end{array}$ & 3.60 & 3.90 & +0.30 \\
\hline Prepare thoroughly for tutorials & 3.10 & 3.53 & +0.43 \\
\hline Produce coursework at the required standard & 3.15 & 3.64 & +0.49 \\
\hline Ask for help if you don't understand & 3.42 & 3.88 & +0.46 \\
\hline Plan appropriate revision schedule & 2.79 & 3.41 & +0.62 \\
\hline Remain adequately motivated throughout & 2.66 & 3.24 & +0.58 \\
\hline Produce your best work in coursework assignments & 3.17 & 3.58 & +0.41 \\
\hline
\end{tabular}

The most notable areas of improvement as shown in Table 1.6 were with:

'Producing your best work under examination conditions', showing a mean increase of 0.74 (from 2.59 to 3.33) and 'Managing your workload to meet coursework deadlines', showing a mean increase of 0.71 (from 3.27 to 3.98 ).

Increases were also found with 'Attain good grades in your work', with a mean increase of 0.62 , and 'Planning an appropriate revision schedule' showing a mean increase of 0.62 
(from 2.79 to 3.41). This aspect was reported by coachees in the focus groups and survey questionnaires to be one of the most useful topics discussed.

\section{Module grade data}

An independent t-test was conducted to compare the overall average module grades of the coached group $(M=57.24, S D=8.8)$ and the non-coached, control group $(M=52.81$, $\mathrm{SD}=13.52) ; \mathrm{t}(239)=2.80, \mathrm{p}=.006$ (two-tailed). The eta squared statistic was calculated to be .03 which demonstrated a small but statistically significant effect size overall.

Table 1.7. Showing mean grade comparisons between coached and control groups.

\begin{tabular}{|c|l|c|c|c|}
\hline \multicolumn{2}{|c|}{ Group } & Number & Mean & Std. Deviation \\
\hline $\begin{array}{c}\text { Average } \\
\text { Grade } \\
\text { Overall }\end{array}$ & Coached & 149 & 57.24 & 8.80 \\
\cline { 2 - 5 } & Control & 92 & 52.81 & 13.52 \\
\hline $\begin{array}{c}\text { Average } \\
\text { Grade } \\
\text { Semester A }\end{array}$ & Coached & 146 & 56.54 & 9.34 \\
\cline { 2 - 5 } & Control & 92 & 52.16 & 14.14 \\
\hline $\begin{array}{c}\text { Average } \\
\text { Grade } \\
\text { Semester B }\end{array}$ & Coached & 127 & 58.57 & 10.90 \\
\cline { 2 - 5 } & Control & 72 & 54.70 & 14.61 \\
\hline
\end{tabular}

The independent t-test was repeated to compare the average semester A module grades of the coached group $(\mathrm{M}=56.54, \mathrm{SD}=9.34)$ and the non-coached, control group $(\mathrm{M}=$ $52.17, \mathrm{SD}=14.14) ; \mathrm{t}(236)=2.63, \mathrm{p}=.009$ (two-tailed). The eta squared statistic was calculated to be .03 which again demonstrated a small but statistically significant effect size overall.

The same independent t-test was repeated to compare the average semester $B$ module grades of the coached group $(M=58.57, S D=10.91)$ and the non-coached, control group $(\mathrm{M}=54.71, \mathrm{SD}=14.62) ; \mathrm{t}(197)=2.63, \mathrm{p}=.053$ (two-tailed). The eta squared statistic was calculated to be .02 which again demonstrated a small but statistically significant effect size overall. 


\section{Exploring the effect on students studying different courses}

Having established a small effect size for the participants as a whole, calculations were then performed for students from each of the different academic schools. The small sample sizes for the academic schools did not allow for reliable findings other than for those students in Life and Medical Science, Law, and the Business School. Further calculations showed a significant difference in student module grades of those from the Business School only. The independent t-test revealed a significant difference in the overall module grades of the coached group $(M=57.75, S D=9.74)$ and the non-coached group ( $M=51.38, S D=12.66$ ); $t(72)=2.44, p=.02$ (two tailed). The eta squared statistic was calculated to be .08 which demonstrates a moderate effect size. It is worth noting that the peer coaching within the Business School was extremely well established, the scheme being in its third year of delivery. Many of the peer coaches were in their second year of participation in the programme and the scheme itself well-embedded within the department. This may be a contributing factor in the success of the programme for Business School students in particular.

\section{Year group}

Independent samples t-tests were performed for students in all four year groups to compare the results of those who received coaching to those in the equivalent control group. The results for Year 3 and 4 students can be ignored due to the low number of participants in these years. The tables in Figure 6 show the different results for each of the year groups:

Figure 6. Showing the difference in attainment for different year groups.

Year of study $=3^{\text {rd }}$ year

\begin{tabular}{|c|c|c|c|c|c|}
\hline & Group & $\mathrm{N}$ & Mean & $\begin{array}{c}\text { Std. } \\
\text { Deviation }\end{array}$ & $\begin{array}{c}\text { Std. Error } \\
\text { Mean }\end{array}$ \\
\hline $\begin{array}{c}\text { Average } \\
\text { Grade }\end{array}$ & Coached & 14 & 59.51 & 7.52 & 2.01 \\
\cline { 2 - 6 } & Control & 6 & 54.89 & 6.84 & 2.79 \\
\hline
\end{tabular}


Year of study $=2^{\text {nd }}$ year

\begin{tabular}{|c|c|c|c|c|c|}
\hline & Group & $\mathrm{N}$ & Mean & $\begin{array}{c}\text { Std. } \\
\text { Deviation }\end{array}$ & $\begin{array}{c}\text { Std. Error } \\
\text { Mean }\end{array}$ \\
\hline $\begin{array}{c}\text { Average } \\
\text { Grade }\end{array}$ & Coached & 52 & 56.48 & 7.61 & 1.05 \\
\cline { 2 - 6 } & Control & 39 & 53.99 & 14.03 & 2.24 \\
\hline
\end{tabular}

Year of study $=1^{\text {st }}$ year

\begin{tabular}{|c|c|c|c|c|c|}
\hline & Group & $\mathrm{N}$ & Mean & $\begin{array}{c}\text { Std. } \\
\text { Deviation }\end{array}$ & $\begin{array}{c}\text { Std. Error } \\
\text { Mean }\end{array}$ \\
\hline $\begin{array}{c}\text { Average } \\
\text { Grade }\end{array}$ & Coached & 81 & 57.18 & 9.64 & 1.07 \\
\cline { 2 - 6 } & Control & 47 & 51.56 & 13.81 & 2.01 \\
\hline
\end{tabular}

No significant increase in average grades was found between those in the $2^{\text {nd }}$ and $3^{\text {rd }}$ year of study and those students in each of the equivalent control groups. However, for those in the first year of study there was a significant increase in average grade for those who were coached $(M=57.18, S D=9.64)$ and those in the control group $(M=51.56, S D=13.81) ; t$ $(126)=2.70, p=.008$, two tailed). The magnitude of the different means (mean difference $=5.62,95 \% \mathrm{Cl}: 1.50$ to 9.73 ) was small (eta squared $=0.05$ ).

From these calculations it could be concluded that the peer coaching was more effective in increasing grades for those students in their first year of study. Whilst the increase in grades is statistically small, it is likely to impact more effectively in overall degree attainment and graduation, as the skills learned through peer coaching can be implemented in subsequent years of learning.

\section{Attrition}

Exploration was also made into the number of students who had withdrawn from their studies. In the control group it was found that by the end of the academic year, a total of 19 students had withdrawn, a total $20 \%$ of the students. In the coached group, 11 students had withdrawn from their studies by the same date, a total of $9.9 \%$. Whilst it is evident that there was less attrition in the coached group it should be remembered that the grades of the students in the control group were also lower overall. This may have been a contributory factor in the lower attrition rate as well as their being a self-selected group. 


\section{Conclusion and discussion}

It can be seen from this evidence that the peer coaching has impacted significantly on academic performance, although it is more evident for some students than others. In particular it appears to have had more impact on those in the Business School and for those in their first year. It is likely that the improvement in academic attainment seen in the first year students will continue into subsequent years as it has for other interventions (Nicol, 2009; O'Donovan et al., 2004). The qualitative evidence would suggest that those who were coached had increased academic confidence and were more enlightened about the requirements of their course. These are benefits that have been reported to be desirable as students enjoy their studies more (Putwain and Sander, 2014) and they become more likely to complete their course (Robbins et al., 2004).

Although the qualitative results might initially appear very positive, it should be noted that the increases may have occurred naturally through the passage of time alone or even through other interventions and support received. Bong (2001) suggests, however, that students with a strong sense of self-efficacy are willing to invest greater effort and persistence in completing challenging tasks. Robbins et al. (2004) noted that the best psychosocial and study skills predictor of academic performance are academic selfefficacy and achievement motivation. Therefore, the increased scores found in the selfefficacy of the coached students may have resulted in higher levels of performance. The qualitative evidence presented, however, suggests that the perception of improved academic performance of the coached students is greater than the actual impact found statistically.

It has been shown that those in the coached group had a lower attrition rate than those in the control group. This has previously been reported as a benefit of mentoring and other peer support schemes (Andrews and Clark, 2011). Whilst coaching has been demonstrated to be effective in increasing hope, cognitive hardiness and in decreasing self-reported symptoms of depression (Green and Rynsaardt, 2007), it has not so far been linked to improved retention in higher education. Whilst this was not the intended focus for the peer coaching intervention, these additional benefits could all be considered important factors in enhancing the reputation of an $\mathrm{HEI}$, particularly when they occurred after a relatively short term intervention. This could be important for HEls' strategy as the financial 
savings from preventing a student leaving prematurely in their first year of study is even greater than for those in subsequent years.

If peer coaching can improve grades and academic behaviour confidence then it may also be a worthwhile consideration as a measure to address the attainment gap in black and minority ethnic (BME) students or to support those with identified lower retention rates, such as mature students or those from widening participation backgrounds.

Further study is suggested using a similar methodological approach, incorporating the use of a control group. It would be of value to incorporate other factors, such as prior academic attainment, socioeconomic backgrounds, to determine impact of peer coaching on academic attainment. A longitudinal study would also be beneficial to determine whether the impact on attainment in the first year students, which has been demonstrated in this study, continues into subsequent years.

Peer support has frequently been reported to be beneficial in the context of higher education. Whilst there are many variations in the delivery of such schemes, it has been shown in both this study and previous work, such as Capstick et al. (2004), that the oneto-one support of a peer is particularly well regarded. Further research to establish where a one-to-one intervention, such as peer coaching, might be more appropriate for particular groups of students than group work could be useful in planning HEI strategies.

The case study institution is unique in having such sizeable peer support interventions and a dedicated team for delivery. This may limit the transferability of the findings to others HEls that do not have such resources. The benefits may be reliant on the robustness of the peer coaching practice as has been seen for other peer support programmes (Husband and Jacobs, 2009; Andrews and Clark, 2011; Thomas, 2012).

Consideration should also be given to the impact that seems to have occurred in the raised levels of student satisfaction in the students who received coaching. This increase was moderate and cannot be directly attributed to the peer coaching, although it is likely to have contributed to the improvement seen from pre- to post-coaching. As HEls compete to attract students and to maintain or increase their position in the league tables, this outcome should not be ignored. The position of an HEI in the National Student Survey league tables is likely to have a strong impact on the attraction of potential students, as 
reported by James et al. (1999). If peer coaching can improve student satisfaction scores as well as increase academic confidence and attainment within a relatively short timescale, then it is an intervention worth consideration.

\section{Appendix 1}

Pre- and post-coaching: Sander and Sanders (2009) Academic Behaviour Confidence Scores

\begin{tabular}{|c|c|c|c|}
\hline $\begin{array}{l}\text { QUESTION (Likert scale 1-5) } \\
\text { Confidence in your ability to: }\end{array}$ & $\begin{array}{c}\text { Pre- } \\
\text { coaching } \\
\text { mean } \\
\text { score }\end{array}$ & $\begin{array}{l}\text { Post- } \\
\text { coaching } \\
\text { mean } \\
\text { score }\end{array}$ & $\begin{array}{l}\text { Increase/ } \\
\text { Decrease }\end{array}$ \\
\hline $\begin{array}{l}1 \text { Study effectively on your own in } \\
\text { independent/private study }\end{array}$ & 3.35 & 3.92 & +0.57 \\
\hline $\begin{array}{l}2 \text { Produce your best work under examination } \\
\text { conditions }\end{array}$ & 2.59 & 3.33 & +0.74 \\
\hline $\begin{array}{l}3 \text { Respond to questions asked by lecturer in front } \\
\text { of a full lecture theatre }\end{array}$ & 2.57 & 3.12 & +0.55 \\
\hline $\begin{array}{l}4 \text { Manage your workload to meet coursework } \\
\text { deadlines }\end{array}$ & 3.27 & 3.98 & +0.71 \\
\hline $\begin{array}{l}5 \text { Give a presentation to a small group of fellow } \\
\text { students }\end{array}$ & 3.43 & 3.88 & +0.45 \\
\hline 6 Attend most taught sessions & 4.12 & 4.33 & +0.21 \\
\hline 7 Attain good grades in your work & 3.08 & 3.70 & +0.62 \\
\hline $\begin{array}{l}8 \text { Engage in profitable academic debate with your } \\
\text { peers }\end{array}$ & 3.08 & 3.40 & +0.32 \\
\hline $\begin{array}{l}9 \text { Ask lecturers questions about the material they } \\
\text { are teaching, in a one-to-one setting }\end{array}$ & 3.60 & 3.90 & +0.30 \\
\hline $\begin{array}{l}10 \text { Ask lecturers questions about the material } \\
\text { they are teaching, during a lecture }\end{array}$ & 2.83 & 3.33 & +0.50 \\
\hline $\begin{array}{l}11 \text { Understand the material outlined and } \\
\text { discussed with you by learners }\end{array}$ & 3.31 & 3.63 & +0.32 \\
\hline 12 Follow the themes and debates in lectures & 3.33 & 3.55 & +0.22 \\
\hline 13 Prepare thoroughly for tutorials & 3.10 & 3.53 & +0.43 \\
\hline 14 Read the recommended background material & 2.86 & 3.24 & +0.38 \\
\hline 15 Produce coursework at the required standard & 3.15 & 3.64 & +0.49 \\
\hline 16 Write in an appropriate academic style & 3.12 & 3.47 & +0.35 \\
\hline 17 Ask for help if you don't understand & 3.42 & 3.88 & +0.46 \\
\hline
\end{tabular}




\begin{tabular}{|l|c|c|c|}
\hline 18 Be on time for lectures & 4.10 & 4.34 & +0.24 \\
\hline $\begin{array}{l}19 \text { Make the most of the opportunity of studying } \\
\text { for a degree at university }\end{array}$ & 3.51 & 3.73 & +0.22 \\
\hline 20 Pass assessments at the first attempt & 3.49 & 3.68 & +0.19 \\
\hline 21 Plan appropriate revision schedule & 2.79 & 3.41 & +0.62 \\
\hline 22 Remain adequately motivated throughout & 2.66 & 3.24 & +0.58 \\
\hline $\begin{array}{l}\text { 23 Produce your best work in coursework } \\
\text { assignments }\end{array}$ & 3.17 & 3.58 & +0.41 \\
\hline 24 Attend tutorials & 4.20 & 4.32 & +0.12 \\
\hline
\end{tabular}

\section{References}

Andrews, J. and Clark, R. (2011) Peer mentoring works; how peer mentoring enhances student success in higher education. Birmingham: Aston University.

Astin, A.W. (1984) 'Student involvement: a developmental theory for higher education', Journal of College Student Personnel, 25(4), pp. 297-308.

Bandura, A. (1993) 'Perceived self-efficacy in cognitive development and functioning', Educational Psychologist, 28(2), pp. 117-148.

Bong, M. (2001) 'Role of self-efficacy and task-value in predicting college students' course performance and future enrolment intentions', Contemporary Educational Psychology, 26(4), pp. 553-570.

Capstick, S., Fleming, H. and Hurne, J. (2004) 'Implementing peer assisted learning in higher education: the experience of a new university and a model for the achievement of a mainstream programme'; Peer Assisted Learning Conference 2004. Bournemouth University, Bournemouth 21 January.

Chao, G.T. (1998) 'Invited reaction: challenging research in mentoring', Human Resource Development Quarterly, 9(4), pp. 333-338. 
Charlton, J.P., Barrow, C. and Hornby-Atkinson, A. (2006) 'Attempting to predict withdrawal from higher education using demographic, psychological and educational measures', Research in Post Compulsory Education, 11(1), pp. 31-47.

Cohen, J.W. (1988) Statistical power analysis for the behavioural sciences. Hillsdale, NJ: Lawrence Erlbaum Associates.

Creswell, J. and Plano Clark, V. (2011) Designing and conducting mixed methods research. Thousand Oaks, CA: Sage Publications.

Crozier, R. (1997) Individual learners: personality differences in education. London: Routledge.

D'Abate, C.P., Eddy, E.R. and Tannenbaum, S.I. (2003) 'What's in a name? A literaturebased approach to understanding mentoring, coaching, and other constructs that describe developmental interactions', Human Resource Development Review, 2(4), pp. 360-384.

Donegan, M., Ostrosky, M. and Fowler, R.S. (2000) 'Peer coaching: teachers supporting teachers', Young Exceptional Children, Volume 3, Spring, pp. 9-16.

Fox, A. and Stevenson, L. (2005) 'Exploring the effectiveness of peer mentoring of accounting and finance students in higher education', Accounting Education: An International Journal, 15(2), pp. 189-202.

Gibson, S. (2005) 'Whose best interests are served? The distinction between mentoring and support', Advances in Developing Human Resources, 7(4), pp. 470-488.

Goodlad, S. (1998) 'Students as tutors and mentors', in Goodlad, S. (ed.) Mentoring and tutoring by students. London: Kogan Page, pp. 1-17.

Green, L. S. \& Rynsaardt, J. (2007) Evidence-based life coaching for senior high school students: Building hardiness and hope. International Coaching Psychology Review, 2, 24-32. 
Griffin, B. (1995) 'Student mentoring to facilitate university entry', Mentoring \& Tutoring for Partnership in Learning, 3(2), pp. 21-24.

Hill, R. and Reddy, P. (2007) 'Undergraduate peer mentoring: an investigation into processes, activities and outcomes', Psychology Learning and Teaching, 6(2), pp. 98-103.

Husband, P. and Jacobs, P. (2009) 'Peer mentoring in higher education: a review of the current literature and recommendations for implementation of mentoring schemes', The Plymouth Student Scientist, 2(1), pp. 228-241.

Ives, Y. (2008) 'What is 'coaching'? An exploration of conflicting paradigms', International Journal of Evidence Based Coaching and Mentoring, 6(2), pp. 100-113.

Ives, Y. and Cox, E. (2012) Goal focused coaching. New York: Routledge.

Jacobi, M. (1991) 'Mentoring and undergraduate academic success: a literature review', Review of Educational Research, 61(4), pp. 505-532.

James, D.L., Baldwin, G. and McInnis, C. (1999) Which university? The factors influencing the choices of prospective undergraduates. Melbourne: Melbourne Centre for the Study of Higher Education.

Johnson, R.B. and Onwuegbuzie, A.J. (2004) 'Mixed methods research: a research paradigm whose time has come', Educational Researcher, 33(7), pp. 14-26.

Kuh, G.D., Palmer, M. and Kish, K. (2003) 'The value of educationally purposeful out-ofclass experiences', in Skipper, T.L. and Argo, R. (eds.) Involvement in campus activities and the retention of first year college students. The First-Year Monograph series. Columbia: University of South Carolina, National Resource Center for the First Year Experience and Students in Transition, no. 36, pp. 19-34.

Lowe, H. and Cooke, A. (2003) 'Mind the gap: are students prepared for higher education?', Journal of Further and Higher Education, 27(1), pp. 53-57. 
Martirosyan, N., Saxon, D.P. and Wanjohi, R. (2014) 'Student satisfaction and academic performance in Armenian higher education', American International Journal of Contemporary Research, 4(2), pp. 1-5.

McKenzie, K. and Schweitzer, R. (2001) 'Who succeeds at university? Factors predicting academic performance in first year Australian university students', Higher Education Research \& Development, 20(1), pp. 21-33.

Medd, W. (2012) Coaching for research in UK Higher Education institutions: a review. In Vitae (Ed.) Research Councils UK. CRAC (Careers Research Advisory Centre).

Mosley, P. (1997) The use of Control Groups in Impact Assessment for Microfinance. Discussion Papers in Development Economics. Enterprise and Cooperative Development Department Social Finance Unit, University of Reading.

Nicholson, L., Putwain, D., Connors, L. and Hornby-Atkinson, P. (2013) 'The key to successful achievement as an undergraduate student: confidence and realistic expectations?', Studies in Higher Education, 38(2), pp. 285-298.

Nicol, D. (2009) Quality enhancement themes: the first year experience', in Education. Linney Direct: The Quality Assurance Agency for Higher Education.

O'Donovan, B., Price, M. and Rust, C. (2004) 'Know what I mean? Enhancing student understanding of assessment standards and criteria', Teaching in Higher Education, 9(3), pp. 325-335.

Pajares, F. and Schunk, D. (2006) The development of academic self-efficacy. San Diego: Purdue University.

Parsloe, E. and Wray, M. (2000) Coaching and mentoring. London: Kogan Page.

Putwain, D. \& Sander, P. (2016) Does the confidence of first-year undergraduate students change over time according to achievement goal profile? Studies in Higher Education, 41, 381-398. 
Robbins, S.B., Lauver, H.L., Davis, D., Langley, R. and Carlstrom, A. (2004) ‘Do psychosocial and study skill factors predict college outcomes? A meta-analysis', Psychological Bulletin, 130(2), pp. 261-288.

Sanchez, R., Bauer, T. and Paronto, M. (2006) 'Peer-mentoring freshmen: implications for satisfaction, commitment and retention to graduation', Academy of Management Learning \& Education, 5(1), pp. 25-37.

Sander, P. and Sanders, L. (2009) 'Measuring academic behavioural confidence: the ABC scale revisited', Studies in Higher Education, 7(1), pp. 19-35.

Short, E. and Baker, S. (2010) Using peer coaching to enhance resilience. University of Bedfordshire: Centre for Excellence in Teaching and Learning.

Stober, D. and Grant A.M. (2006) 'Toward a contextual approach to coaching models', in Stober, D. and Grant A.M. (eds.) Evidence-based coaching handbook. New York: Wiley, pp. 17-50.

Thomas, L. (2012) What works? Student retention and success. London: Paul Hamlyn Foundation and Higher Education Funding Council for England.

Tinto, V. (1993) Leaving College: rethinking the causes and cures of student attrition, Chicago, University of Chicago Press.

Torres, J.B. and Solberg, V.S. (2001) 'Role of self-efficacy, stress, social integration and family support in Latino college student persistence and health', Journal of Vocational Behaviour, 59(1), pp. 53-63.

Ward, E., Thomas, E. and Disch, W. (2010) 'Goal attainment, retention and peer mentoring', Academic Exchange Quarterly, 14(2), pp. 170-176.

Whitmore, J. (2002) Coaching for performance. London: Nicholas Brealey Publishing.

Yorke, M. (2002) 'Academic failure: a retrospective view from non-completing students', in Peelo, M. and Wareham, T. (eds.) Failing students in higher education. Buckingham: Open University Press, pp. 29-44. 
Zajacova, A., Lynch, S.M. and Espenshade, T.J. (2005) 'Self-efficacy, stress and academic success in college', Research in Higher Education, 46(6), pp. 677-706.

\section{Author details}

Dr Jill Andreanoff is an independent researcher, consultant and author of a book on exemplary practice coaching and mentoring in higher education. She currently works in an Employability Consultancy capacity for the University of Essex, UK, for both the Strategic Planning and Change Section and within their Employability and Careers Centre. 